\title{
Crossing enemy boundaries: al-Buhturì's ode on the ruins of Ctesiphon re-read in the light of Virgil and Wilfred Owen
}

\author{
STEFAN SPERL \\ School of Oriental and African Studies
}

\begin{abstract}
I find myself facing the Other. He is neither a cultural signification nor a simple given. He is, primordially, sense (..) because only through him can a phenomenon such as signification introduce itself, of itself, into being.
\end{abstract}

(Levinas, 2003: 30)

After a brilliant career at the heart of empire, the 'Abbāsid court poet alBuhturī found himself disillusioned with royal patronage. In AD 883 he set out in doleful mood to find solace in the vestiges of another empire which his own people, the Muslim Arabs, had humbled and defeated two centuries earlier: Sasanid Persia and the by now abandoned ruins of its capital, Ctesiphon. The contemplation of the majestic remains of its royal palace - the great central arch of which stands to this day-inspired him to compose a masterpiece which is ranked among the finest specimens of classical Arabic literature and has been subject to much critical attention, especially in recent times. ${ }^{1}$

The circumstances of the poem's composition have been examined in the light of previous scholarship by Waqayyān, who also provides an extensive commentary on the poem's thematic development which stresses al-Buhturī's outstanding skill in the domain of wasf or poetic description (1985: 179-97). Focusing on the highly unusual manner in which al-Buhturī's portrayal of the ruined palace remoulds the traditional Arab poetic theme of the atlal, the abandoned campsite, Serrano explains the poet's encounter with the Sasanian past as an attempt to reclaim his own poetic heritage by means of 'travelling to an imagined alternative, alien and ancient tradition' (1997: 86). ${ }^{2}$ In a similar vein, Meisami sees the poem as a reassertion of the poet's fortitude in adversity and his belief in moral values (1998: 73-4), thus taking exception to the approach of Jaroslav Stetkevych who views it as a melancholy ode dominated by a mood of 'loss and remembrance' in the vein of the nasīb, the conventional erotic prelude of the qașida (1993: 190-91). ${ }^{3}$ More recently, Sumi subjected the poem to a close reading as part of her study on wasf, description in classical Arabic poetry. Like Stetkevych, she sees the poem primarily as a reverie on bygone glory, occasioned by al-Buhturì's personal misfortune and the political decline of the 'Abbāsids. In association with David Quint's notion of the 'loser's epic', Sumi goes so far as to describe the work as a 'loser's qasida', exhibiting 'reiteration and aimlessness' and hence 'a deviant structure' (2004: 118).

Notwithstanding their different conclusions, these studies all approach the poem by seeking to define and interpret it in the context of classical Arabic poetics and its conventional themes, in particular wasf, ațāl and nasìb. In comparing the poem to a work on the same topic by the Persian poet Xāqāni

${ }^{1}$ See al-Buhturī, 1972: 1152-62. Full English translations of the poem are found in Arberry (1965: 73-80), Serrano (1997) and Sumi (2004: 101-08).

${ }^{2}$ An extended version of this article appeared as chapter 1 in Serrano (2002).

${ }^{3}$ See also Meisami's comparison of al-Buhturī’s ode with Khāqānī's poem on the same topic (1996: 174-6). 
Sharvāni, Jerome Clinton has taken a rather different approach. $\mathrm{He}$ is primarily concerned with what is surely the most remarkable feature of alBuhturî's poem, namely the extraordinary transformation in the psychological state of the poet which leads from one of loathing and disgust for humanity at the beginning of the work to an outpouring of love for 'men of honour from every root and stock' in the last line. However, there seems to be an unresolved contradiction in Clinton's findings. He interprets the ringing tones of the poem's conclusion as a 'brief moment of communion' between Arabs and Sasanians, as the poet realizes that 'nobility is a universal constant that transcends the boundaries of race and time' (1977: 199). Subsequently, however, Clinton argues that this moment of communion is in fact the process of a 'gradual and implicit naturalization of the Sasanians to his own affinity group'-namely the Arabs, a process he describes, in a brief but compelling analysis, as being at the core of the poem's structure (1977: 202). Yet if this were so the 'boundaries of race and time' would not have been crossed at all, but simply conjured away by the poet: the Sasanians, the poem would then suggest, are not alien at all but really Arabs at heart.

As indicated by the title, the present paper argues for a different interpretation of al-Buhturî's mental metamorphosis - one suggested by two other works that exhibit a similarly profound change of mood which, moreover, takes place in circumstances marked by some surprising parallels. The first is an extract from The Aeneid by Virgil (d. 19 BC), the other is a well-known work by Wilfred Owen (d. 1918), the poem 'Strange Meeting' which was set to music in memorable fashion by Benjamin Britten as part of his War Requiem. While the three texts are each some 1,000 years apart and hail from entirely different cultural spheres they have this in common: each of them originates in an imperial entity - the Rome of Augustus, the 'Abbassid Caliphate and the British Empire - and each portrays a moment of sudden and overwhelming intimacy in the encounter with an actual or emblematic foe of this imperial might: Carthage in the case of Virgil, Persia in the case al-Buhturī and Germany in the case of Owen. Each of them thus conveys a boundary crossing experience in which the cleavage between hostile entities is transcended by the sudden perception of a common bond which supersedes, however fleetingly, their legacy of conflict.

As a first step the extract from Virgil will be introduced with the aim of tracing the characteristic stages of the transformation involved. The paper then proceeds to examine what shape these same stages assume in the poems by al-Buhturī and Owen before concluding with a more extensive comparison of the three texts and an assessment of the wider significance of the type of experience involved.

\section{In the temple of Juno}

Virgil's Aeneid is widely regarded as the foundation epic of the Roman Empire. It tells the story of Aeneas, a Trojan prince who flees the burning ruins of his native city and reaches Italy, the land of his ancestors, after a long and tiresome voyage. There he engages in wars which bring about the foundation of Rome and establishes a dynasty that was ultimately to spawn Augustus, Emperor and patron of Virgil. Aeneas' travails are decreed by Jupiter who promised to grant the new city 'empire without end' (imperium sine fine dedi, Aeneid, 1:279). ${ }^{4}$ Jupiter's grand design, however, is bitterly opposed by his

\footnotetext{
${ }^{4}$ Extracts from The Aeneid are cited in the translation of H. R. Fairclough throughout (see Virgil 2001).
} 
consort Juno, enemy of the Trojans, who seeks to employ every stratagem to destroy Aeneas and spoil his mission.

The extract in question occurs at the beginning of the epic when, after suffering storm and shipwreck, Aeneas reaches the coast of Carthage and decides to explore this unknown land in the company of one of his men, Achates. We find him here in such a state of despondency and loss that he wishes he had not survived the sack of Troy. Instead of dying a hero's death, he has become a nameless outcast: 'Myself unknown and destitute, I wander over Libyan wastes, driven from Europe and from Asia' (1:384). To make matters worse, Carthage is the very bastion of his arch enemy, the Goddess Juno; and it is Carthage, rather than any future Rome, which Juno has selected to rule the world: 'here was her armour, here her chariot, here should be the capital of nations' $(1: 16-7)$.

Despite these inauspicious circumstances it so happens that Aeneas finds consolation in, of all places, the mighty temple of Juno which Dido, the Queen of Carthage, has erected in honour of the Goddess and which Aeneas and Achates come to view as they enter the capital on their peregrinations. This is the first 'boundary crossing experience' I would like to discuss. Virgil describes it as follows:

hoc primum in luco nova res oblata timorem

leniit, hic primum Aeneas sperare salutem

ausus et adflictis melius confidere rebus.

namque sub ingenti lustrat dum singular templo,

reginam opperiens, dum, quae fortuna sit urbi,

artificumque manus inter se operumque laborem

miratur, videt Iliacas ex ordine pugnas

bellaque iam fama totum vulgate per orbem,

Atridas Priamque et saevum ambobus Achillem.

constitit et lacrimans, 'quis iam locus', inquit, 'Achate,

quae regio in terris nostri non plena laboris?

en Priamus! Sunt hic etiam sua praemia laudi;

sunt lacrimae rerum et mentem mortalia tangunt.

solve metus; feret haec aliquam tibi fama salutem'.

sic ait. Atque animum picture pascit inani

multa gemens, largoque umectat flumine vultum.

In this grove first did a strange sight appear to him and allay his fears; here first did Aeneas dare to hope for safety and put surer trust in his shattered fortunes. For while beneath the mighty temple, awaiting the queen, he scans each object, while he marvels at the city's fortune, the handicraft of several artists and the work of their toil, he sees in due order the battles of Ilium, the warfare now known by fame throughout the world, the sons of Atreus, and Priam, and Achilles, fierce in wrath against both. $\mathrm{He}$ stopped and weeping cried: 'Is there any place, Achate, any land on earth not full of our sorrow? See, there is Priam! Here, too, virtue finds its due reward; here, too, are tears for misfortune and human sorrows pierce the heart. Dispel your fears; this fame will bring you some salvation.' So he speaks and feasts his eyes on the unsubstantial portraiture, sighing oft, and his face wet with a flood of tears (1:450-65).

These celebrated lines present the reader with something of a mystery. Not only does Aeneas find himself in the very sanctuary of his arch enemy but, as Johnson notes, 'the frescoes that delight and hearten him are a kind of victory 
monument to Juno: they depict crucial, pathetic moments in the ruin of Troy, a ruin in which Juno, of course, takes a savage, ineffable delight'. We are thus left 'pondering the question, What in the world does Aeneas see here that cheers him up?' (1976: 103-04). ${ }^{5}$ A preliminary answer would seem to be that discovering these representations of the tragic fate of his people and his city makes him realize that instead of being unknown and alone as he had imagined, the fame of the Trojans has preceded him even in this menacing and alien land. The pictures appear to him as expressions of sympathy borne out of emotions he can recognize as kindred to his own: respect for virtue and pity for human loss. The significance of this insight, this moment of recognition, is stressed by Virgil's repeated use of the word 'here' (hic): in the initial lines of the epic cited above it emphasizes the status of Carthage as Juno's abode: 'here was her armour, here her chariot' (hic illius arma, hic currus fuit, 1:16-7); yet it is also here, in the very sanctuary of his sworn enemy, that Aeneas first dares to find hope (hic ... sperare salutem ausus, 1:451); indeed, 'here, too', virtue finds reward (sunt hic etiam sua premia laudi, 1:459).

The simple words 'here, too', hic etiam, can thus be said to encapsulate the essence of this boundary crossing experience which resides in the discovery that the other side, too, appears to share identical feelings and values and, most notably a sense of compassion for the victims of misfortune. The issue of compassion is stressed in the subsequent exchange between Dido and Aeneas. Moved by the Trojan's plight, the Queen decides to give asylum to the fugitives, whereupon Aeneas addresses her as the only one who 'pitied Troy's unutterable woes' (sola infandos Troiae miserata labores, 1:597) and wishes her a worthy reward 'if there is justice anywhere' (si quid usquam iustitiae est, 1:604-05).

However momentary and, indeed, illusory the experience may be, it is a pivotal event, involving a highly significant constellation of space and time whereby three distinct stages may be distinguished. The starting point is an exilic experience of discomfiture and loss which leads the unwitting protagonist to a location at the very heart of the enemy camp. The second stage is one of contemplation as he comes face-to-face with images which bring into play two contrasting temporal aspects: the transience of man on the one hand, and the permanence of his fame on the other. The result is both sorrow and relief: sorrow over mortality, as expressed in the famous, untranslatable phrase lacrimae rerum, 'tears over things', best circumscribed perhaps as 'tears over the great and tragic events of history'; and relief at having found salvation through being recognized as a human being worthy of such tears and such esteem.

\section{In the ruins of Ctesiphon}

Stages of a similar kind may be distinguished in the qașìda by al-Buhturì. It, too, begins with a protagonist in the throes of dejectedness and depression. Searching for solace, he proceeds to the abandoned palaces of the Sasanian capital, where he comes face-to-face with images depicting a great war and a glorious past, though it is that of a rival nation and former enemy, the Persians. Like Aeneas, the experience reduces al-Buhturī to tears and restores his faith in humanity. The palace of Ctesiphon, capital of the Sasanian empire, shares with the temple of Juno the status of a prime enemy location and the association with an enemy cult, as exemplified in the belief that the arch of

\footnotetext{
${ }^{5}$ For another recent discussion of this extract and its function in the context of Virgil's epic see Putnam (1998).
} 
Ctesiphon was cleft open on the day the Prophet Muhammad was born and the Zoroastrian fires kept there were extinguished. ${ }^{6}$ The Arabs' victory over the Persians in the battle of Qādisiyya and their subsequent conquest of the Sasanian capital remain seminal events to this day whose memory was much invoked during the recent war between Iraq and Iran. Ctesiphon is thus at the heart of a cleavage between cultural entities periodically engaged in rivalry and conflict. Nevertheless, the visit to Ctesiphon reduces al-Buhturī to tears and restores his faith in humanity. Borrowing Johnson's phrase, we might well ask, What in the world does al-Buhturī - a poet so aware of his Arab credentials'see here that cheers him up'?

Al-Buhturī's poem happens to give a detailed insight into precisely this issue because the work as a whole is designed to convey the transformation of consciousness undergone by the poet. As noted elsewhere, the qașida as a literary form is admirably suited for this purpose as it traces the stages of transformation involved, not in the form of a narrative, but through a sequence of different images whose symbolism allows a deeper insight into the process at hand. ${ }^{7}$ As in Virgil's passage, the repetition of an apparently insignificant word can be said to mark the key stages of the transformation achieved. Here it is kull (all, every), which occurs at the beginning, middle and end of the work. It features in the very first line:

\section{1. Șuntu nafsī 'ammā yudannisu nafsī} wa-taraffa'tu 'an jadā kulli jibsī

I have shielded myself from what defiles my self

I have risen above the pittance of every niggard.

This expression of defiance sets in motion a train of thought which depicts the world as having fallen under the sway of lowliness and disgrace to such an extent that the meaning of the poet's life is called into question. His departure from his native Syria and his move to Iraq appear to him as nothing more than loss-making transactions and he now finds himself rejected even by his nextof-kin. In a wish to dissociate himself from such ignominy the poet turns away from his contemporaries and seeks solace in the ancient ruins.

It is here, in a place of emptiness and death-like desolation, that he sees evidence of the greatness which he has come to miss among the people of his time and which, to his discomfiture, appears to have surpassed that of his Arab ancestors. Having made this grudging observation, the poet begins to contemplate a series of paintings depicting the battle of Antioch ${ }^{8}$ and is profoundly struck by what he finds. The soldiers in the battle scenes are depicted in such a lifelike fashion that he feels compelled to trace the images with his hands:

\section{Yaghtalì fìhimū rtiyābì hattā tataqarrāhumū yad̄̄ya bi-lamsī}

Such wonder over them rises up within me that

My hands explore their features by touch.

With this moment of marvel we reach the exact middle of the poem (line 28 of 56), at which point a profound change of mood sets in, marked by the recurrence, in an altogether different context, of the key word kull. For suddenly the

\footnotetext{
${ }^{6}$ A noted example of the topos is found in al-Būșīrī’s Qașìdat al-Burda (see Sperl and Shackle, 1996, vol. 2: 397).

${ }^{7}$ See Sperl (1996: 65-77).

${ }^{8} \mathrm{~A}$ battle fought between the Sasanians and the Byzantines in AD 540.
} 
poet's son appears and offers his father a copious draft of wine (line 29) which grants solace and joy as though it were:

\section{Ufrighat fì l-zujāji min kulli qalbin fa-hya mahbūbatun ilā kulli nafsī}

Poured into the cup of every heart,

Thus dearly loved by every soul/self.

This expression of delight generously granted to 'every heart' (kullu qalbin) and 'every soul' ( $k$ ullu nafsi) contrasts greatly with the mood in the first line of the poem in which the lone soul ( $n a f s \bar{i})$ of the poet is aggressively set against defilement by 'every niggard' ( $k$ ullu jibsì). It is indicative of the new, all-embracing sense vision which emerges as the poem unfolds and comes to full fruition at the end of the work. At this stage it results in a bewitching fantasy in which al-Buhturī, under the spell of his magic beverage, imagines himself in the role of the Sasanian Emperor, entertained by the court musician Balahbadh and with the Emperor's son Khusrau Parviz, as boon companion. ${ }^{9}$

The following sections of the poem proceed to retrace, at a heightened level, the stages of the poet's emancipation from his initial dejectedness. Lines 35-44, focusing on transience, conjure up the immense, sombre arch and the battlements which, even in their looted and despoiled state, appear to defy time in a manner which recalls the poet's strength in adversity set out at the beginning of the work. ${ }^{10}$ A second contemplative passage then follows which shows the poet once more in a state of marvel as the past seemingly comes back to life (lines 45-50). This time, however, it is not paintings but the fruit of his own imagination which he describes. As he reaches 'the limits of his perception' (idhā mà balaghtu ākhara hissì, 45) he suddenly sees the palace thronged with courtiers, emissaries and singing girls, all of whom seem to have departed not centuries but only days ago.

As the work progresses it becomes clear that the poet is not only seized by growing admiration for the greatness of the ancient Persians but that he experiences an increasing, almost physical, closeness to them and identifies himself with them to a deepening extent. It is this closeness which frees the poet from his misanthropic state. The key moment of transition is experienced twice, involving in both cases a straining of the senses to reach out to the other: the first time when he is impelled to touch the paintings with his hands to check whether they are alive or not, a gesture which expresses in physical terms his being once more 'in touch' with the world; the second time when, upon reaching 'the limits of his perception', he sees in his mind's eye the image of the palace as it used to be at the height of its glory. The first experience leads to a reawakening of joy in human companionship and wine, the second brings the poem to its cathartic climax as the realization that all this human grandeur is irretrievably lost unleashes a flow of tears brought on by grief and, indeed, by love:

\section{0. 'ummirat li l-surūri dahran fa-șārat lil-ta'azzì ribā'uhum wa l-ta'assī}

\footnotetext{
${ }^{9}$ Waqayyān points out that al-Buhturī here appears to echo the verses of the Umayyad poet Ādam b. 'Ábd al-'Aziz who also imagined himself in the role of Kisrā after drinking a draft in his memory in the ruins of Madā'in (1985: 186, for the text see al-Ișfahānī, 1983: xv, 229). On the topos of 'drinking in ancient palaces and feeling on top of the world' see also the poems by alMunakhkhal al-Yashkurī (text in al-Așma'ī, 1963: 60) and Abū 1-'Atāhiya (text in Arberry, 1965: 46-50) where revelling takes place in the palaces of al-Khawarnaq and al-Sadīr.

${ }^{10}$ As noted by Meisami, "the vicissitudes which have afflicted the palaces figure those which afflict the poet; the palaces' fortitude figure his own' (1998: 74).
} 


\section{1. fa-lahā an u'inahà bi-dumūìn mūqafātin 'alà l-șabābati ḥubsì}

52. dhāka 'ind̄̄ wa laysati l-dāru dārī bi-qtirābin minhā wa là l-jinsu jinsì

Built to delight for a time, their quarters

Now belong to grief and mourning.

So it behoves me to aid them with tears Inalienably bequeathed to them through love.

This I do have and yet the abode's not mine

By kinship, nor is the race my race.

Lines 51 and 52 echo the beginning of the poem in a subtle illustration of the long trajectory covered in its course. In the introduction, the word subāba, "the last drops of liquid left over in a vessel', is used to convey the miserable deal granted the poet by the stinginess of Time:

3. Bulaghun min subābati l-'ayshi 'indī țaffafathā l-ayyāmu tațĭfa bakhsī

Bare sufficiency of life's last drops is all I have

The days have doled them out in short measure.

This contrasts greatly with the poet's own generosity at the end when, seized by love (sabāba!), he grants the ruins his tears in an inalienable, thus timeless, bequest. Whereas at the beginning he had but 'bare sufficiency' (bulaghun 'indī), by the end he emphatically declares that he has these copious tears (dhāka 'indī!) and is ready to shed them even though the abode is not his. The encounter with the ruins has thus impelled the poet to engage in an act of virtuous generosity which counters the niggardliness of the age, frees him from his self-imposed withdrawal from mankind, and thereby enables him to be creative once more. For the actual manifestation of this timeless bequest of tears is undoubtedly the poem itself, and the driving force behind this act of creation is love, as stated in the last line where the key word kull is found once more:

56. arān̄̄ min ba'du aklafu bi l-ash-

räfi turran min kulli sinkhin wa issī

I now find myself in love with men of honour

Without exception, from every root and stock.

The poem thus moves from the rejection of every niggard (kullu jibsi, 1), via the wine of a new vision granted to every heart and soul (kullu qalbin, kullu nafsi, 32), to love of the noble from every root and stock (kullu sinkhin wa issi, 56). The key stages of the transformation involved thereby mirror those identified in the extract from The Aeneid. Here, too (hic etiam!) we have found:

1. An exilic state of isolation and dejection, coupled with arrival at an alien location with hostile associations;

2. The contemplation of images in this location which leads to a surprising recognition of shared feelings and values with respect to human transience and the abiding worth of high endeavour.

3. A state of reintegration marked by shared tears of grief over mortality, coupled with solace through new-found human bonds.

A remarkable structural feature of al-Buhturī's poem is that, as noted above, it repeats stages two and three twice over. The poem can therefore be divided 
into three parts, the first dwelling upon the exilic state while the second and third convey the twice repeated moment of contemplation and reintegration; each is introduced by lines dwelling upon transience and death and each exhibits a subtle alternation between the imaginary and the real. In the first movement, the contemplation of real paintings depicting the battle of Antioch leads to a drunken fantasy as the poet sees himself in the role of the Sasanian monarch. Then, after his fantasy vision of the ancient palace in its heyday, he experiences a deep and real moment of reconciliation with humanity as a whole. The images of wine and tears link the two stages in a significant manner: he is offered the wine and, in turn, he offers his tears.

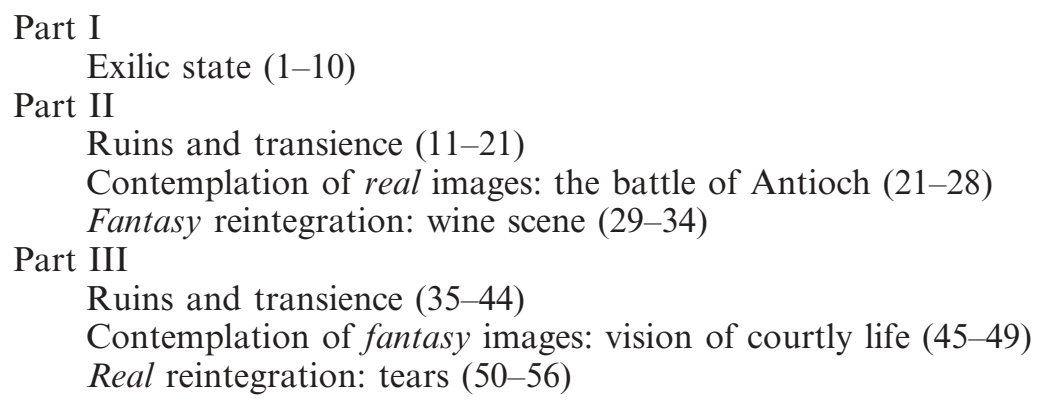

Though brief, this structural survey of the poem is sufficient to cast doubt on Sumi's contention that it is a 'loser's qasida' with a deviant or aimless structure; on the contrary, the poem exhibits a clear and highly targeted sense of direction, stressed by the contrasting linkages between beginning and end.

\section{In the caverns of Hell}

An altogether different, and yet in key respects familiar, array of these themes is found in the poem 'Strange Meeting' by Wilfred Owen (1994: 35-7). Written in 1918 under the impression of the trench wars in which the author had participated as a British army officer, it relates an imaginary encounter between himself and a stranger who, at the end of the poem, reveals himself as an enemy soldier whom the poet had killed in battle. At the beginning figures, once more, a departure in exilic, solitary fashion:

It seemed that out of battle I escaped

Down some profound dull tunnel, long since scooped

Through granites which titanic wars had groined. (1-3)

The poem goes on to confirm, in a particularly stirring way, that 'crossing an enemy boundary' in the manner here discussed involves first and foremost an act of recognition. Remarkably, here, it is not the protagonist or the poet who does the recognizing, but the former enemy. It is also he who, in turn, helps the poet to recognize what place he had unwittingly escaped to out of battle, a location more inauspicious even than Juno's temple:

Then, as I probed them, one sprang up, and stared

With piteous recognition in fixed eyes,

Lifting distressful hands, as if to bless.

And by his smile I knew that sullen hall,-

By his dead smile I knew we stood in Hell. (6-8).

As we read on it becomes clear that this act of recognition results from a mental kinship, an identical perception of being, to which the nameless enemy 
gives vent in a long monologue which provides the core of the poem and which can be viewed as equivalent to the 'contemplation of images' in the two texts discussed above. It begins by emphasizing the similarities between the two men-'Whatever hope is yours was my life also' (15-16) - and goes on to reflect on two key themes also encountered in the other texts, grief over transience, and the abiding value of virtuous endeavour. The angle of vision, however, is dramatically different. The passage does not grieve over men who accomplished greatness and then perished, like the Trojans and the Sasanians, but over those who never lived to accomplish it at all. As stated in Welland's noted interpretation of the poem, if only they could have held themselves apart from the process of disintegration, had they only had the opportunity

To miss the march of this retreating world

Into vain citadels that are not walled

they might, in the fullness of time, have been empowered to arrest that march and restore the truth' (Welland, 1960: 102). Instead, mankind has suffered irreparable loss, 'irreparable not for what they were but for what they would have been, not for what they gave but for what they would have given' (p. 103).

Greatness is, as seen by Virgil and al-Buhturī, also here rooted in human virtue:

Courage was mine, and I had mystery,

Wisdom was mine and I had mastery. (30-31)

In the earlier texts, however, such courage and mastery are most clearly manifest in warfare, as illustrated in the images of the battles of Troy and Antioch which adorn Juno's temple and the Sasanian palace respectively. The point made in Owen's poem is strikingly different. The virtuous traits of men such as the fallen enemy and, indeed, of the poet himself, were never meant to be expended for the sake of war:

I would have poured my spirit without stint

But not through wounds; not on the cess of war. (37-38)

The final passage of the poem resumes the theme of recognition once more in a particularly poignant way:

'I am the enemy you killed, my friend.

I knew you in the dark: for so you frowned

Yesterday through me as you jabbed and killed.

I parried; but my hands were loath and cold.

Let us sleep now ...'. (40-44)

In their suggestion of peace and rest, the words 'let us sleep now' call to mind the solace found by Aeneas and al-Buhturī in their respective experiences of recognition, but they might well convey no more than a resigned descent into the darkness of non-being. Benjamin Britten's great musical rendering of the phrase in the War Requiem, however, expands and amplifies it into a song of reconciliation which ends his work on a note of sorrow tinged with hope.

The theme of tears, an integral part of the cathartic response to the encounter in both Virgil and al-Buhturī, is found also in Owen's poem, where it figures in a manner strangely reminiscent of al-Buhturì's qașìda for here, too, tears are clearly a metaphor for poetry:

and of my weeping something had been left,

Which must die now. I mean the truth untold,

The pity of war, the pity war distilled. (23-25) 
The passage suggests that the unknown enemy was a poet with a message similar to that of the author himself. Indeed, Owen's poetry is motivated by precisely such pity which impels him to tell the unadorned truth about the suffering of war in ways that earned him criticism from committed patriots both during his life and after. ${ }^{11}$

The fact that the poet's weeping 'must die now', that his words will be silenced, is at the heart of the 'irreparable loss' which the work as a whole conveys: his young life is cut short, the truth will not be told and pity not be shown. In al-Buhturī's case, by contrast, the perspective, though sorrowful, gives vent to far more hope. His tears are not cut short but mūqafāt, bequeathed for ever more, a phrase which, by association with a topos as common in Arabic poetry as in Shakespeare's sonnets, constitutes a metaphor for the anticipated fame and longevity of his poem. Al-Buhturī was of mature age and at the height of his powers when he wrote this work, and the phrase conveys the confidence of a master aware of the lasting value of his craft. Owen was only 25 when, only a few months after composing this poem, he shared the fate of his imagined enemy and friend.

\section{The self restored}

Having outlined certain parallels in the three texts and thus determined that it is through the act of recognition that the boundaries between enemies are here overcome, the question of who recognizes whom needs to be examined in more detail, for the answer appears to be quite different in each case.

The striking aspect of Virgil's passage is that it involves not one but multiple acts of mutual recognition: the people of Carthage recognize the tragic virtue of the Trojans and depict them thus, and Aeneas in turn recognizes the Trojans as kindred spirits when he sees these images. What has by far the greatest emotional impact upon Aeneas, however, is that he recognizes none other than his own people in the images painted in Juno's temple; indeed,

\section{se quoque principibus permixtum agnovit Achivis}

Himself, too, in close combat with the Achaean chiefs he recognized. $(1: 488)$

As noted above, in Owen's poem the act of recognition proceeds from the enemy side, but here, too, there is a strong suggestion that what is being recognized is not the alterity of the other but the image of one's own self within him. Welland pointed out that "the imaginative force of "Strange Meeting" ... resides in the fact that it is not a friend or an enemy that the soldier meets as much as an alter ego' (Welland, 1960: 100). In a subsequent study, Bäckmann develops the observation in greater detail and points to the association between Owen's vision and certain variants of the ancient 'Doppelgänger' motif in which the alter ego is killed by the protagonist or seen in a dream or as an apparition (Bäckmann, 1979: 114). It follows that, just as Aeneas sees his identity as a great but tragic hero made manifest in the pictures found in the temple of his greatest foe, so Owen sees his great but tragic poetic mission made manifest in the words of recognition spoken by the enemy he has killed in battle.

\footnotetext{
${ }^{11}$ Robert Graves is reported to have told Owen to 'cheer up and write more optimistically' whereupon the poet composed an 'Apologia pro poemata meo' which ends with the words

You shall not come to think them well content

By any jest of mine. These men are worth

Your tears. You are not worth their merriment (Owen, 1994: 19).
} 
In al-Buhturì's poem, on the other hand, the situation seems to be more one-dimensional since the images the poet sees are those of Sasanians depicting themselves, and the poet is thus clearly faced with nothing but their alterity. However, a closer look at one particular theme which runs right through the poem, that of exaltedness and elevation both physical and moral, suggests otherwise. The theme appears in the very first line which, moreover, contains a conspicuous emphasis on the notion of selfhood through the repetition of the word nafs:

\section{1. Șuntu nafsī 'ammā yudannisu nafsī} wa taraffa'tu 'an jadā kulli jibsī

I have shielded myself from what defiles my self

I have risen above the pittance of every niggard.

The moral exaltedness of the poet here expressed in the phrase taraffa'tu 'an is subsequently mirrored in the tallness of the Sasanian structures as expressed in the double collocation of the roots 'alà (to be high) and sharufa (to be high born, illustrious) in lines 14 and 41, whereby the root rafa' $a$ (to lift up) occurs once more:

\section{Wa humū khāfiḍūna fì żilli 'àlin mushrifin yahsiru l-'uyüna wa yukhsī}

They (the Sasanians) were luxuriating, shaded by a high (palace) Overlooking (all), which humbles and strains the (onlooker's) eyes.

\section{Mushmakhirrun ta'lū lahū shurufātun} rufi'at fì ru'ūsi Raḍā wa Qudsī

Soaring up, with high battlements

Raised above the heads of Radwā and Quds

The two lines appear to make covert allusions to the supremacy of the Sasanian achievements as compared to the Arabo-Islamic heritage to which the poet belongs. By association with Quran 67:4 (yanqalibu l-basaru ilayka khāsi'an wa huwa hasīr, 'your glance reverts to you dazzled and vanquished'), the Sasanian palace is implicitly likened in splendour to the whole of God's creation, which cannot be perceived but as a daring, if not outrageous, thought in orthodox eyes. The same point is made more overtly in line 41, which describes the Persian battlements as raised 'above the heads of Radwā and Quds'. The latter are usually glossed as mountains but the names have unmistakeable Islamic overtones. ${ }^{12}$ This thinly disguised sleight at his own kinsmen goes to show that the poet's sense of virtue and honour, which he had missed in his contemporaries, is found to be manifest in the Persians. Like Aenas and Owen, al-Buhturī thus discovers, and recovers, his own embattled self in the encounter with the other. The act of recovery is sealed and the circle closed in the last line, where the poet quite literally describes himself as 'seeing himself'; significantly, the root sharufa recurs once more, here denoting the exalted men of honour of all nations for whom the poet has found love:

\section{Arānī min ba'du aklafu bi- l-ashräfi țurran...}

I now see myself in love with men of honour

${ }^{12}$ Serrano also notes thematic aspects of the poem which appear to contravene Islamic tenets, including the reference to wine drinking and songstresses (1997: 82-3, 85); the latter are, however, common poetic motifs and need not necessarily be viewed as intentionally unorthodox. 


\section{The alienated self}

In the light of the above we must conclude that the three texts appear to be variants of one underlying experience. In all three, the act of crossing the boundary to the 'enemy' brings about the recovery of a lost or alienated self. Just as the act of recognition is fundamental to that recovery, so the exilic state of loss with which the movement begins is characterized by the fact that the self is not recognized by others or, worse, that it has become unrecognizable even to itself. In Virgil this moment is reached when Aeneas, in profound dejection, describes himself as ipse ignotus, 'myself unkown' (1:384), whereupon his divine mother Venus feels impelled to appear and speak encouraging words: 'whoever you are, not hateful to the powers of heaven do you draw the breath of life' (quisquis es, haud, credo, invisus caelibus auras vitalis carpis, 1:387-8). Aeneas, however, finds no comfort until he discovers the pictures in the temple. Returning now once more to Johnson's earlier question of what Aeneas sees in there 'that cheers him up', the answer seems unequivocally clear. He sees himself - and therein lies the moment of catharsis. This reading, which is strongly suggested by comparison with the other two texts, is not shared by Johnson who concludes, wrongly I would argue, that 'there is nothing in the pictures to cheer Aeneas, and in fact he is not cheered' (1976: 103). For him, the whole episode is nothing but a case of tragic self-delusion. However, while Aeneas was, as much as Dido, deluded about what destiny had in store for them and for Carthage, the self-restoration he experienced in Juno's temple is, for him, palpably real.

In al-Buhturi's poem, the threat of alienation undergone by the self in the exilic condition looms in the very first line as the poet expresses his resolve to counter it with determination:

\section{1. Șuntu nafsì 'ammā yudannisu nafsì \\ I have shielded myself from what defiles my self}

Non-recognition as a feature of this crisis is clearly spelled out in line 7 when the poet, having spoken of his physical and mental discomfiture, defiantly addresses an unnamed companion as follows:

\section{Là taruzn⿳亠 muzāwilan li- khtibārī ba'da hādhì l-balwā fa-tunkira massī}

Don't weigh me up in order to test me

After this misfortune, just to disown my touch.

The words imply that the poet's state has so deteriorated that his companions are inclined to shun him, whereby the verb ankara also carries the here highly pertinent meaning of 'pretending not to recognize'. It is the poet's contemptuous response to this rejection which impels him to leave his kinsmen in favour of the vestiges of the Sasanian past (see lines 8-11).

In Owen's poem, the theme of the 'alienated self' appears in a particularly stirring guise. The beginning of the poem tells us nothing about the poet's mental state before arriving at the place of his encounter with the stranger; it only states that he 'seemed to have escaped out of battle'. Not until the end, when the strange figure reveals his identity, do we find out what the poet had been engaged in:

I knew you in the dark: for so you frowned

Yesterday through me as you jabbed and killed. (40-43) 
Such violence, however, is precisely what the poet's true self, as mirrored in that of his alter ego, would not have wished to partake in:

I would have poured my spirit without stint

But not through wounds; not on the cess of war. (37-38)

The truly remarkable feature of the act of recognition in this poem is, therefore, that the stranger recognizes and understands the poet's true self-his self as a friend and kindred spirit - even in its most alienated state when, mired in 'the cess of war', it no longer sees but only 'frowns through' and 'jabs'.

\section{War and peace}

In all three texts the condition of the 'alienated self' reflects a moment of crisis in the protagonists' self-identification with the imperial entities to which they belong. In The Aeneid we are faced with a temporary eclipse of fortune in the period between the destruction of Troy and the foundation of Rome during which Aeneas loses faith in his imperial destiny, a faith which Virgil himself seems not to have unreservedly upheld, judging by his emotive portrayal of the carnage and bloodshed which the erection of the imperial edifice would enact. ${ }^{13}$ In the case of al-Buhturī, too, a crisis of self-identification with the aims of the state which he had served is in evidence when we see the eulogist of 'Abbāsid Caliphs turning his back on the court in Baghdad, casting aspersions overt and veiled at its ethnic and religious foundations, and depicting himself as a Sasanian monarch. In Owen's text, the critique of the powers that be is particularly palpable as he depicts his contemporaries engaged in a collective march to ruin:

None will break ranks though nations trek from progress (29)

Owen's critical stance is openly expressed in a sarcastic fragment with the revealing title 'An Imperial Elegy' in which the whole of Europe appears as a graveyard of titanic size that crosses the continent 'like a mystic road' and carries the name 'the Path to Glory' (see Owen, 1994: 83).

Judging by these texts it would thus seem that we cannot, or do not, seek to recognize ourselves in our adversaries until our own foundations are in the process of disintegration. No less sobering is the realization that this salutary act of recognition with its promise of salvation (Aeneas), love (al-Buhturī) and friendship (Owen) is in all three texts portrayed to varying degrees as ephemeral islands of tranquillity in the midst of seas of war, as conjured up by the battle fields of Troy, Antioch and Northern France. Moreover, the peace which reigns on these islands - a peace which makes the encounter possible in the first place - is but the fruit of death and destruction. In Owen's work, recognition and friendship are relegated to the afterlife when both combatants have effectively annihilated each other and, even there, not to Heaven, but to the caverns of a Dantesque Hell where it constitutes but a brief and 'strange meeting' while the Great War rages on unabated.

Perhaps more tragic still is the illusory union between the Trojan fugitives and the Carthaginians which is as though suspended between two cataclysmic experiences of defeat. Emerging from the sack of Troy, Aeneas believes he has found rescue while Queen Dido, moved by pity and deceived by the Gods, believes she has found love. It is this very meeting between them, however,

${ }^{13}$ This view is stressed inter alia by the so-called 'Harvard School' of Virgilian critics who argue that 'the dark side of political success and the cost of imperialism, a cost felt by victor and victim' constitutes the 'essential message' of the Aeneid (Harrison, 1990: 5). 
which would eventually lead to the sack of Carthage and the annihilation of its kingdom at the hands of the Roman army. ${ }^{14}$ In a moment of tragic irony, their new-found bond is celebrated with copious drafts of wine while a court musician 'makes the hall ring with his golden lyre' (1:740-41). Thus 'did unhappy Dido prolong the night with varied talk and drank deep draughts of love' (1:749), unaware of the separation and utter destruction this union would bring in its wake.

This drinking scene in The Aeneid has an unexpected counterpart in alBuhturî's work. As mentioned above, at the heart of the poem the new-found Arabo-Persian entente is consecrated in an imaginary gathering of wine and song as Chrosraw Parviz hosts the poet to the tunes of the legendary court musician Balahbadh (1. 33). The resemblance is, of course, purely fortuitous, but it prompts the question whether al-Buhturī's conciliatory vision, too, reflects no more than a brief interlude of drunken rapture when violence and war momentarily abate. No doubt, his empathy with the former Sasanian enemy is only possible because the latter has been defeated and no longer constitutes a threat, and his former greatness and demise may thus be safely mourned. Moreover, the theme of battle reappears at the end of the poem as the Persians are praised for having, in ancient days, helped the Arabs defeat a common enemy, the Ethiopians (see lines 52-4). Love for men of honour 'of all root and stock' is thus in no way incommensurable with war, however much the last line of the poem may appear to be an early testimony to humanism and cross-cultural understanding.

\section{Conclusion}

It would seem that reading al-Buhturī's qasida in conjuction with the other two texts has not only led to a deeper understanding of its structure and thematic development but also granted a comparative insight into what may be a universal literary theme. For 'crossing enemy boundaries' has shown itself in all three texts to be not so much a quest for the enemy as such, but a search for the self within the enemy, a search born out of alienation and loss and a need for healing through human recognition.

The encounter between self and other which forms the core of the boundary crossing experience in the three texts can be read as a vindication of certain philosophical tenets upheld by Emmanuel Levinas in his theory of humanism. For him, 'significance originally emerges from the face-to face encounter as an ethical event, that is, from the other person as a moral command and the self as a moral response' (Cohen in Levinas, 2003: xxx). The experience of recognition which marks the transformation of consciousness in the three texts and rescues the self from its alienation can be seen as nothing less than the 'emergence of significance' in Levinas' terms, whereby 'significance' refers to the self's entire sense of identity and purpose. In Levinas' view, the emergence of significance through the encounter with the other is not the result of cultural conditioning but, rather, precedes, and resides at the root of, culture: 'before cultural expression, before the said, lies the universal but deformalized humanism of the other, the saying of the other as another human being' whose very existence, once apprehended, constitutes an 'unconditional ethical imperative' (Levinas: xxxii).

\footnotetext{
${ }^{14}$ When Aeneas decides to leave Dido for Italy she utters a prophetic curse which brings about perpetual strife between Carthage and the clan of Aeneas and ultimately leads to the Punic wars and the destruction of Carthage itself (see Aeneid 4:615-29).
} 
The pivotal events depicted in our texts can be seen as evidence of just such an imperative: Aeneas' salvation through images conveying compassion in the very sanctuary of his enemy, al-Buhturī's gift of tears granted to an alien people, and the slain soldier's welcome of his killer, 'lifting distressful hands, as if to bless'. The fact that texts of such different provenance show evidence of comparable mental processes lends credence to the idea that we are here facing an ethical imperative which is indeed cross-cultural, if not 'pre-cultural'. Of equal significance, however, is the fact that the salutary effect of this ethical imperative is grounded in an experience of loss. The three texts contain ample evidence that only when the might of the imperial self is humbled and aware of both the frailty of itself and the other, can boundaries between enemies be crossed and the ethical impulse which makes us human come to fruition.

\section{BIBLIOGRAPHY}

Arberry, A. J. 1965. Arabic Poetry-A Primer for Students. Cambridge: Cambridge University Press.

Al-Așma‘ī. 1963. al-Așma'iyyāt (ed. 'Abd al-Salām Hārūn). Cairo: Dār al-Ma'ārif.

Bäckmann, Sven. 1979. Tradition Transformed-Studies in the Poetry of Wilfred Owen. Lund: Gleerup.

Al-Buhturī. 1972. Dīwān (ed. Hasan Kāmil al-Șayrafī) vol. 2. Cairo: Dār al-Ma‘āarif.

Clinton, Jerome W. 1977. 'The Madāen Qasida of Xāqāni Sharvāni, II: Xāqāni and al-Buhturī', Edebiyât 2, 191-206.

Dubois, Page. 1982. History, Rhetorical Description and the Epic from Homer to Spencer. Cambridge: Cambridge University Press.

Harrison, S. J. 1990. 'Some views of The Aeneid in the twentieth century', in S. J. Harrison (ed.), Oxford Readings in Vergil's Aeneid. Oxford: Oxford University Press.

Hunt, J. William. 1973. Forms of Glory-Structure and Sense in Virgil's Aeneid. Carbondale and Edwardsville: Southern Illinois University Press; London: Feffer and Simons.

Al-Iṣfahānī, Abū l-Faraj. 1983. Kitāb al-Aghānī. 24 vols. (ed. 'Abd al-Sattār Aḥmmad Faraj). Beirut: Dār al-Thaqāfa (sixth edition).

Johnson, W. R. 1976. Darkness Visible-A Study of Vergil's Aeneid. Berkeley: University of California Press.

Levinas, Emmanuel. 2003. Humanism of the Other (trans. Nidra Poller, introduction by Richard A. Cohen). Urbana and Chicago: University of Illinois Press.

Meisami, Julie Scott. 1996. 'Poetic microcosms: the Persian Qasida to the end of the twelfth century', in S. Sperl and C. Shackle (eds), Qasida Poetry in Islamic Asia and Africa. Vol. 1, Classical Traditions and Modern Meanings. Leiden: E. J. Brill, 137-82.

Meisami, Julie Scott. 1998. 'Places in the past: the poetics/politics of nostalgia', Edebiyât 8, 63-106.

Owen, Wilfred. 1994. The War Poems (ed. John Stallworthy). London: Chatto \& Windus.

Putnam, Michael C. J. 1998. Virgil's Epic Designs-Ekphrasis in the Aeneid. New Haven and London: Yale University Press.

Serrano, Richard A. 1997. 'Al-Buhturī's poetics of Persian abodes', Journal of Arabic Literature 28/ $1,68-87$.

Serrano, Richard A. 2002, Neither a Borrower-Forging Traditions in French, Chinese and Arabic Poetry. Oxford: Legenda (European Humanities Research Centre).

Sperl, Stefan. 1996. 'Qasida form and mystic path in $13^{\text {th }}$ century Egypt', in S. Sperl and C. Shackle (eds), Qasida Poetry in Islamic Asia and Africa. Vol. 1, Classical Traditions and Modern Meanings. Leiden: E.J. Brill, 65-82.

Sperl, Stefan and Christopher Shackle (eds). 1996. Qasida Poetry in Islamic Asia and Africa. vol. 1, Classical Traditions and Modern Meanings; vol. 2, Eulogy's Bounty, Meaning's Abundance-An Anthology. Leiden: E.J. Brill.

Stetkevych, Jaroslav. 1993. The Zephyrs of Najd-The Poetics of Nostalgia in the Classical Arabic Nasīb. Chicago: Chicago University Press.

Sumi, Akiko Motoyoshi. 2004. Description in Classical Arabic Poetry-Wasf, Ekphrasis and Interarts Theory. Leiden: E. J. Brill.

Virgil. 2001. Eclogues, Georgics, Aeneid 1-6 (trans. H. Rushton Fairclough, rev. G.P. Goold). Cambridge, MA and London: Harvard University Press.

Waqayyān, Khalīfa. 1985. Shi'r al-Buhturī-Dirāsa Fanniyya. Beirut:

Welland, Dennis S. R. 1960. Wilfred Owen-A Critical Study. London: Chatto \& Windus. 